\title{
Fertility and population policy
}

\author{
ABDOULAYE OUEDRAOGO, Ph.D.* \\ MEHMET S. TOSUN, Ph.D.* \\ JINGJING YANG, Ph.D.*
}

\section{Article**}

JEL: H10, H59, J11, J13, J18

doi: $10.3326 /$ pse.42.1.2

\footnotetext{
* The authors would like to thank two anonymous referees for useful comments and suggestions.

${ }^{* *}$ Received: February 14, 2017

Accepted: December 28, 2017

Abdoulaye OUEDRAOGO

The World Bank, 1818 H St NW, Washington, DC 20433, USA

e-mail: aouedraogo3@worldbank.org

ORCiD: 0000-0002-8384-4908

Mehmet S. TOSUN

University of Nevada, Reno, Department of Economics, College of Business, University of Nevada-Reno, Reno, Mail Stop 0030. Nevada 89557, USA

e-mail: tosun@unr.edu

ORCiD: 0000-0002-7034-6838

\section{Jingjing YANG}

University of Nevada, Reno, Department of Economics, College of Business, University of Nevada-Reno, Reno, Mail Stop 0030. Nevada 89557, USA

e-mail: jingjingy@unr.edu

ORCiD: 0000-0001-7566-8089
} 
There have been significant changes in both the fertility rates and fertility perception since 1970s. In this paper, we examine the relationship between government policies towards fertility and the fertility trends. Total fertility rate, defined as the number of children per woman, is used as the main fertility trend variable. We use panel data from the United Nations World Population Policies database, and the World Bank World Development Indicators for the period 1976 through 2013. We find a significant negative association between a country's fertility rate and its anti-fertility policy. On the other hand, there is no significant and robust relationship between the fertility rate and a country's pro-fertility or family-planning policies. In addition we find evidence of spatial autocorrelation in the total fertility rate, and spatial spillovers from a government's policy on fertility.

Keywords: fertility rate, population, government policies

\section{INTRODUCTION}

Fertility rates have decreased substantially over the last few decades. While decreases are more profound in developed countries, developing countries have also experienced significant changes following, in some cases, specific government policies. While population control policies vary widely around the world, governments in developing countries tend to have a relatively negative view towards fertility, which often leads to the adoption of anti-fertility policies. It is not clear, however, whether there is indeed a significant or strong relationship between population policies and fertility rates.

In this paper, we examine the relationship between government policies towards fertility and the change in the total fertility rate using panel data on 133 countries over the 1976-2013 period. We use country-level data from the United Nations World Population Policies Database, and the World Bank's World Development Indicators. ${ }^{1}$ In our analysis we consider different types of government policy. The first is to reduce fertility through education, health care, family planning, employment programs and the availability of low-cost contraception. We can refer to this as anti-fertility policy. The second is to raise fertility through a variety of government subsidies for childcare and housing, tax incentives, maternal and paternal leave and media campaigns. We can refer to this as pro-fertility policy. ${ }^{2}$ In addition, within the anti-fertility policy category, we examine family planning policy separately to see if that policy is particularly strongly related to changes in fertility. We also control for country fixed effects and spatial autocorrelation in the data. We present results for different econometric specifications to understand the robustness of our results. Our main findings show a statistically significant, negative relationship between change in total fertility rate and anti-fertility policy. On

\footnotetext{
${ }^{1}$ The UN World Population Policies Database provides data for the years 1976, 1986, 1996, 2001, 2003, 2005, 2007, 2009, 2011, and 2013. Data for 2015 became available very recently but was excluded from our analysis due to lack of data for that year for other variables used in our regressions.

${ }^{2}$ The term "pro-natal policy" is also used in many studies.
} 
the other hand, there is no significant and robust relationship between change in total fertility rate and pro-fertility policy. We also do not find a significant and robust relationship with family planning policy. In addition we find evidence of spatial autocorrelation in the total fertility rate, and spatial spillovers from a government's policy on fertility.

In the next section, we start with a brief discussion of the previous literature and then present trends in the total fertility rate and government policies towards fertility. This is followed by a description of the empirical approach, models and variables used in our analysis. We present our results in section 4 and provide a summary and concluding remarks in the last section.

\section{FERTILITY TRENDS AND POPULATION CONTROL POLICIES}

Other studies that examined whether fertility responds to population policies have had mixed results. Pritchett (1994) argues and shows that the significant variation in fertility rates across countries is due to the desired fertility of couples, and is not driven by the availability of contraceptives or family planning policy by governments. At the same time, Haub (2010) argues that population control policy in South Korea not only worked but worked too well. South Korea now has one of the lowest fertility rates in the world. Singapore is another example where the population policy went from anti-natalist in 1960s and 1970s to pro-natalist after the mid-1980s (Yap, 2003). Yap (2003) notes that the total fertility rate in Singapore rose sharply from 1.6 to about 2 children per woman in 1988, soon after the introduction of the new pro-natalist policy in 1987. Feyrer, Sacerdote and Stern (2008) argue that there may be an increase in the fertility rates in high-income countries due to increased participation of males in the household, which is not necessarily driven by a specific government policy. A recent book by Takayama and Werding (2011) provides an overview of policy responses to low fertility with a particular focus on China, France, Japan, South Korea and Sweden. While there is no consensus on whether there are policies that have clearly worked to raise fertility rates, public involvement may be justified or required in some cases. Studies in the volume also point to difficulties with the available data and the complexity of studying fertility behavior. For example, Bradshaw and AttarSchwartz (2011) examine the relationship between fertility and social policy using the European Social Survey data on sixteen European countries. They point to several problems, particularly with the measurement of social policy variables and do not find strong evidence of a relationship between social policy and fertility.

There have been significant decreases in fertility rates in recent decades. Figures 1 and 2 show the variation in total fertility rates in 1976 and 2013, respectively. Figure 1 shows very high fertility rates (over 5 children per woman) in 90 countries in 1976. Africa and the Middle East had the highest concentration of countries with very high fertility rates. Only 23 countries in Europe and North America had below replacement fertility. Figure 2 shows drastic changes in fertility. In 2013 , the number of countries with very high fertility decreased to 15 , and the 
number of countries with below replacement fertility increased to 73 . While the highest concentration of countries with very high fertility is still in Africa, none of the Middle Eastern countries had very high fertility. Many African countries experienced significant decreases in fertility. Unlike what we observed in the map for 1976, all other European countries (particularly Eastern European countries), and some emerging market economies such as Brazil, China and Turkey also moved to below replacement fertility in 2013 .

\section{Figure 1}

Total fertility rate in 1976

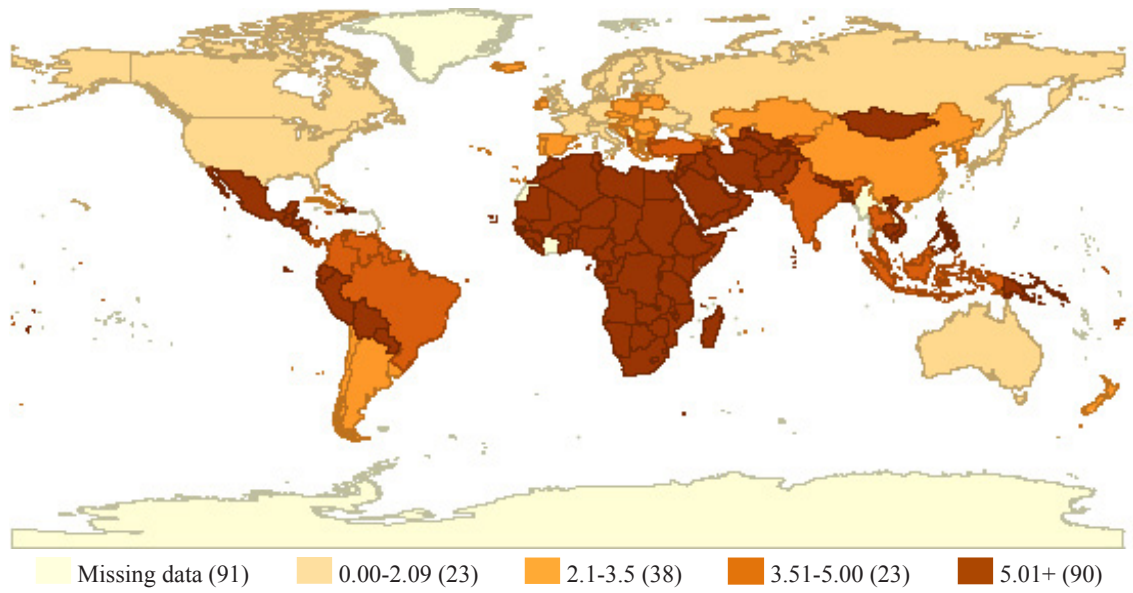

Source: United Nations Population Policies Database, 1976.

Figure 2

Total fertility rate in 2013

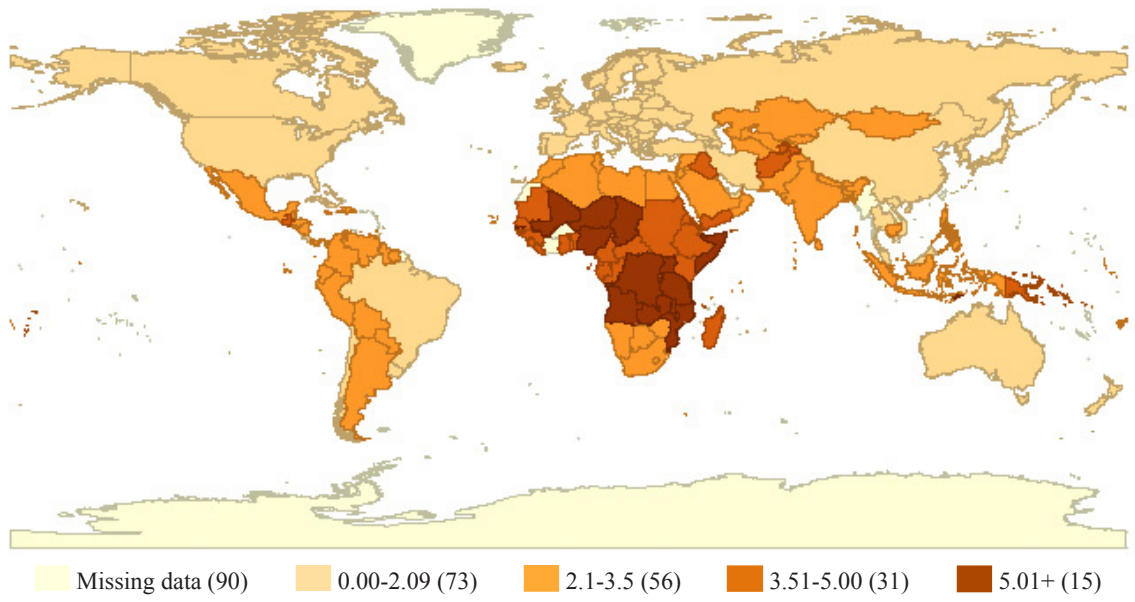

Source: United Nations Population Policies Database, 2013.

We now turn to government policies towards fertility. The United Nations World Population Policy database provides a comprehensive and rich dataset on govern- 
ment attitudes towards fertility and other important demographic variables. ${ }^{3}$ United Nations (2013) notes that the database uses four major sources of information. The first is the official response from the country governments to the inquiries directly sent by the United Nations. The second is government documents, publications, laws, regulations and proclamations. The third is the official materials provided by international and intergovernmental organizations, including other United Nations agencies. The final source is the materials provided by nongovernmental organizations such as media outlets, academic and other research institutions. $^{4}$

The key variable of interest in this database is the "policy on fertility level." United Nations (2013) describes this variable as "a Government's stated policy to influence the level of fertility in the country". Response categories for the variable are "raise", "maintain", "lower", and "no intervention". The map in figure 3 shows how government policies towards fertility differ for countries in our dataset. In 1976 , only 55 countries had an anti-fertility policy. We see that a number of governments in Africa did not have an anti-fertility policy. It is also noteworthy that only 18 countries had a pro-fertility policy in 1976.

\section{Figure 3}

Government policy on fertility in 1976

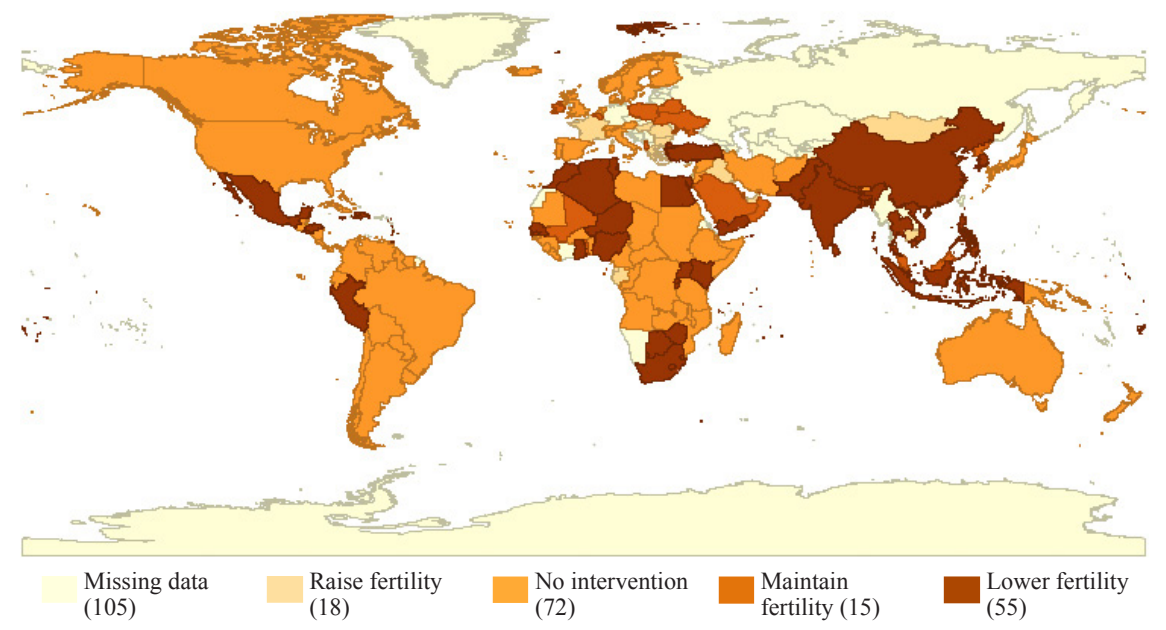

Source: United Nations Population Policies Database, 1976.

While we see a similar pattern in 2013 in figure 4, significantly more governments have anti-fertility policies. At the same time, more governments have adopted pro-fertility policies from 1976 to 2013 . This could be seen as an indication of

\footnotetext{
${ }^{3}$ See United Nations (2013) and https://esa.un.org/poppolicy/img/Definitions_Policy_Variables.pdf for a detailed description of the variables in the database.

${ }^{4}$ See United Nations (2013) for more on these data sources. Box I.1 on page 43 in that publication has a chart that shows both the inputs to the database and major outputs or publications from the database.
} 
concerns regarding the impact of population aging on economies. ${ }^{5}$ Figure 4 shows that the number of governments with an anti-fertility policy rose to 76 , which is significantly greater than the number of governments with such a policy in 1976. In addition, most African countries now have policies to reduce fertility. The number of governments with pro-fertility policies also increased substantially, to 51. In figure 5, we also summarize the time trend in the percent share of countries with policies to reduce and raise fertility. We see a significant increase in the share of countries with policies to reduce fertility between 1986 and 2001 and then a sharp increase in the share of countries with policies to raise fertility after 2001.

\section{Figure 4}

Government policy on fertility in 2013

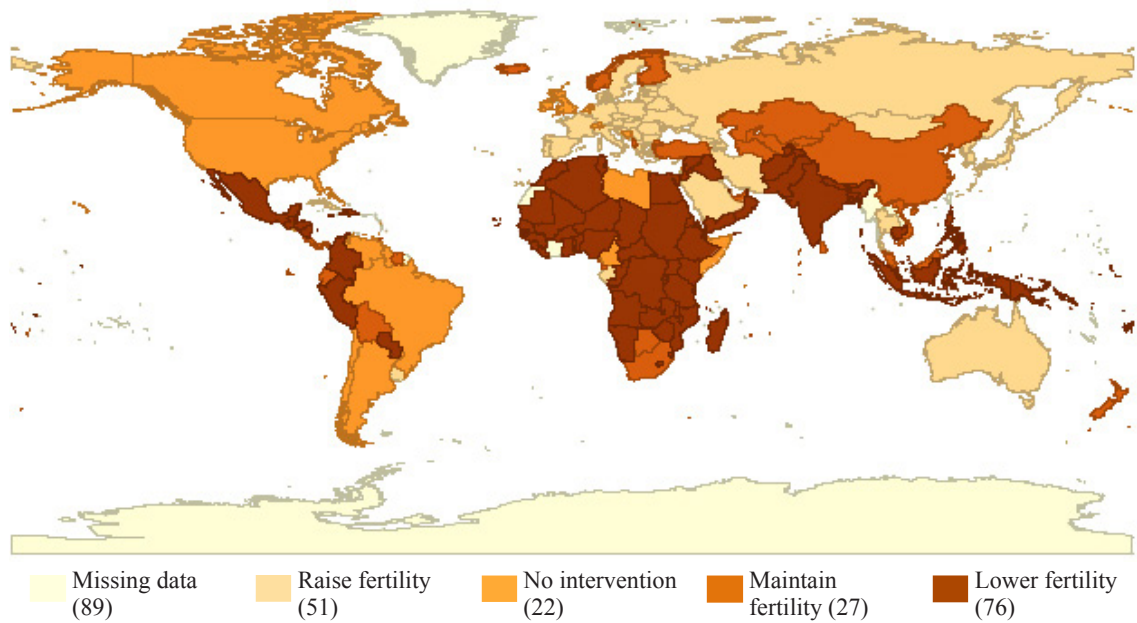

Source: United Nations Population Policies Database, 2013.

\section{Figure 5}

Percent share of countries with anti-fertility and pro-fertility policies

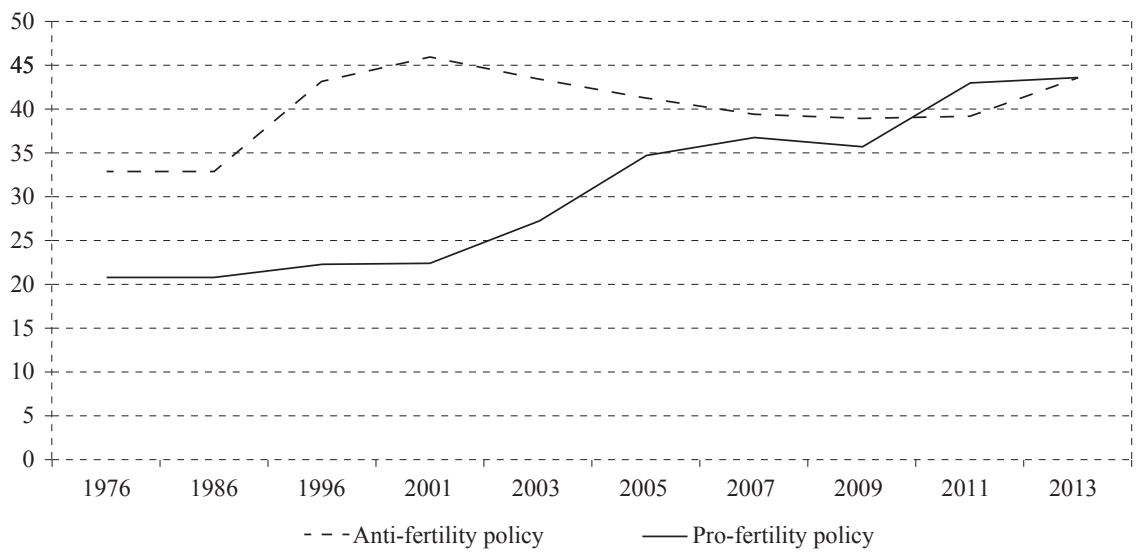

Source: United Nations Population Policies Database, 1976-2013.

\footnotetext{
${ }^{5}$ Note that there are more countries added to the UN World Population Policies Database after 2000.
} 
We also see in figures 3 and 4 that the spatial distribution of the government policies and the total fertility rates are not random. There seems to be a significant degree of spatial clustering among countries. The local indicators of spatial association (LISA) map in figure 6 shows that the spatial correlation in total fertility rates in 1976 is particularly strong among countries with high fertility rates, especially so for Africa and the Middle East. The LISA map in figure 7 shows that this significant spatial association persisted for countries in Africa. These two maps point to the presence of spatial autocorrelation in total fertility rates, which we examine in the next section.

\section{Figure 6}

Local indicators of spatial association (LISA Map), total fertility rate in 1976

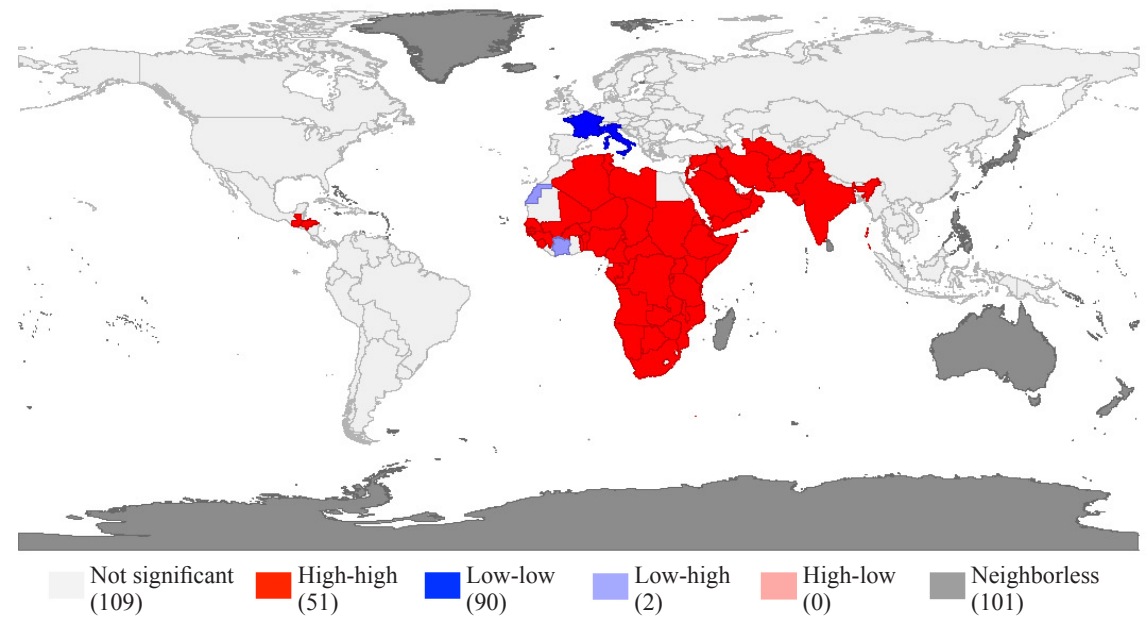

\section{Figure 7}

Local indicators of spatial association (LISA Map), total fertility rate in 2013

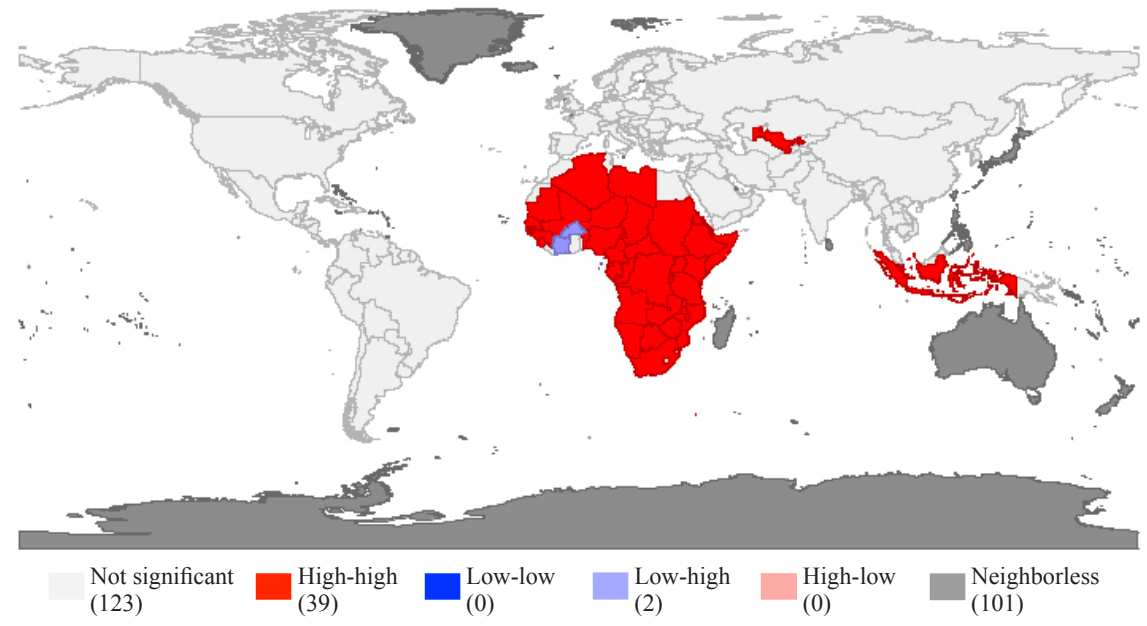


We examine empirically how fertility responds to government policies towards fertility. We use Change in the total fertility rate as the dependent variable. Data on total fertility rate come from the United Nations Population Division. The three key explanatory variables are anti-fertility policy, pro-fertility policy, and family planning policy, which are all constructed from the variables in the United Nations World Population Policies database. Anti-fertility policy is a dummy variable that takes the value 1 if the government has an anti-fertility policy, and 0 otherwise. As we explained in section 2, we used the variable "policy on fertility level" from the United Nations database and recoded the response category "lower" as 1 and other responses ("raise", "maintain", and "no intervention") as 0.

Pro-fertility policy is a dummy variable that takes the value 1 if the government has a pro-fertility policy, and 0 otherwise. For this variable, we used "policy on fertility level" from the United Nations database again, and this time recoded "raise", and "maintain" as 1 and other responses ("lower" and "no intervention") as $0 .{ }^{6}$

Family planning policy is also a dummy variable that takes the value 1 if the government has a policy that supports family planning directly or indirectly, and 0 otherwise. While family planning is mentioned as part of the definition of "policy on fertility level" in the United Nations database, the same database has a separate variable called "government support for family planning". For the variable family planning policy, we used "government support for family planning" from the United Nations database, and recoded "direct support" and "indirect support" as 1 and other responses ("no support" and "not permitted") as 0. Our three explanatory variables are related to each other. Anti-fertility policy is strongly and negatively correlated with pro-fertility policy. Family planning policy is positively correlated with anti-fertility policy but the correlation is not very high (about 0.24). Family planning policy is also negatively correlated with pro-fertility policy. We are using these variables in separate regressions, which gives us a way to compare results across different regressions.

We also use a number of other control variables that include GDP per capita, health spending per capita, trade to GDP, share of urban population, and country fixed effects. GDP per capita is gross domestic product divided by midyear population and measured in constant (2005) US dollars. The relationship between GDP and the fertility rate can be rather complex. While economic development in a country that is measured by GDP per capita can act like a contraceptive, countries at a high level of development may engage in promotion of higher fertility. ${ }^{7}$ Hence we do not have a specific expectation regarding the relationship between the fertility rate and the GDP per capita. Health spending per capita, defined as the ratio of

\footnotetext{
${ }^{6}$ We coded "maintain fertility" response as 1 since a policy to maintain fertility or to prevent fertility from declining would still involve some pro-fertility intervention from the government. We have checked the robustness of our results by coding it as zero and found that our results did not change significantly and qualitatively. ${ }^{7}$ See also Becker (1960), and Razin and Sadka (1995) for theoretical arguments on the relationship between income and fertility.
} 
the sum of public and private health expenditures to total population, is an important variable that controls for a potential impact of the level (and quality) of the health care provided to citizens on their fertility behavior. We might expect a negative relationship to total fertility rate since couples may likely decide to have fewer children if they know that they will receive good healthcare for themselves and their kids. Trade to GDP, defined as the ratio of the sum of exports and imports of goods and services to GDP, captures vulnerability of economies to external shocks. Kim and Prskawetz (2006) argue and show evidence that households use children (or fertility) as a consumption smoothing strategy in response to external shocks. Hence we would expect a positive relationship between trade to GDP and the total fertility rate. We use share of urban population as a control for the level of urbanization.

We apply the spatial econometric methods to estimate the relationship between the government policies towards fertility and change in the total fertility rate. Fertility behavior in one country could correlate with the fertility rates in adjacent countries. A lot of countries in our dataset have relatively open borders with a good degree of mobility among countries. For example, people in many African countries have ethnic, religious or tribal links with others across the border. This could lead to spatial correlation in the fertility behavior. Similarly, government policies on fertility could also have spillover effects on adjacent countries. Central and regional governments interact with those that are in close proximity, which could lead to spatial dependence in fertility policies. There may also be concern for spatial dependence if the policy of aid organizations in one country is driven by their experience in a neighboring country or region. Other studies have pointed to similar spatial or neighborhood effects in developing countries. For example, Parent and Zouche (2012) provide evidence that spatial dependence matters for growth outcomes in Africa and the Middle East. Easterly and Levine (1998) also give evidence of neighborhood effects in growth performance and growth-related policies in African countries.

Statistically, we refer to the standard Moran I test statistic to understand the spatial correlation in the data. Figure 8 shows the Moran's I scatter plot of all countries. ${ }^{8}$ The Moran I test statistic is equal to 0.295 and is statistically significant at the 0.05 level, which means the spatial autocorrelation is significant and cannot be neglected in our data. The $\mathrm{x}$-axis is the value of the total fertility rate of each country, and the y-axis is the corresponding Moran's I values for the country with adjacent countries. The scatter plot shows that generally with the increase of the fertility rate, Moran's I tends to be positive, and vice versa. Most positive Moran's I values are for African countries, while most negative Moran's I values are for countries in Europe. ${ }^{9}$

\footnotetext{
${ }^{8}$ We included a different version of this graph (figure A1) with country codes and a list of countries used in the graph in the appendix section.

${ }^{9}$ We also conducted more detailed spatial diagnostic tests where we find that spatial autocorrelation is a concern in our data.
} 


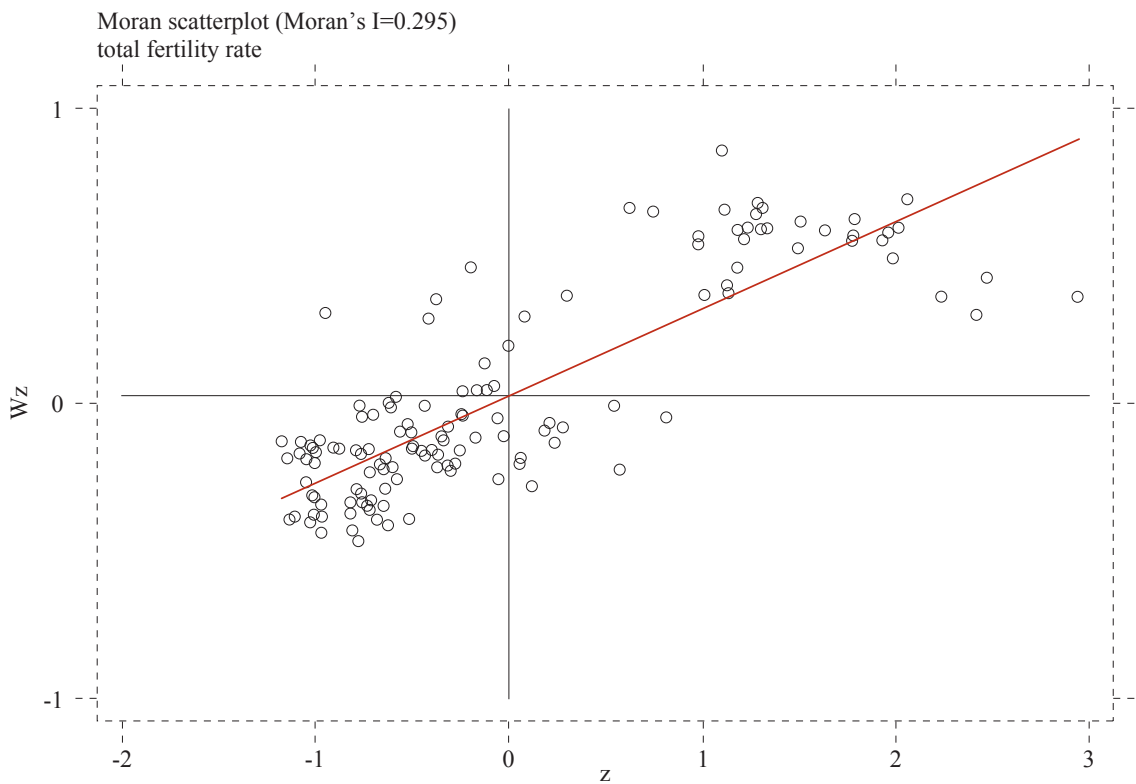

We examine spatial dependence by running spatial lag and spatial error regressions. Models of spatial dependence account for influences from places that are geographically close to each other. Failing to consider spatial dependence may lead to biased, inefficient, or inconsistent coefficient estimates (Cliff and Ord, 1981; Anselin, 1988). A spatial error model contains an autoregressive process in the error term, whereas a spatial lag model assumes a spatially lagged dependent variable. The linear spatial lag or spatial autoregressive model (SAR) can be expressed as:

$$
\text { Change in fertility rate }{ }_{i t}=\alpha_{0}+\rho \text { WFertilityrate }_{i t}+\beta X_{i t}+\gamma_{i}+\tau_{t}+\varepsilon_{i t}
$$

where $W$ denotes the spatial weighting matrix that provides the spatial neighborhood information. There are different ways to generate the spatial matrices. Here we use the inverse distance matrix ${ }^{10} . \rho$ denotes the spatial parameter. $X$ includes the main explanatory and other control variables that are described at the beginning of this section. Finally, each year in the panel data set is controlled for by time fixed effects $(\tau)$, and $\gamma$ represents the country fixed effects in the model. The spatial error model (SEM) can be expressed as:

$$
\text { Change in fertility rate }{ }_{i t}=\alpha_{0}+\beta X_{i t}+\gamma_{i}+\tau_{t}+\varepsilon_{i t} \text {, where } \varepsilon_{i t}=\beta W \varepsilon_{i t}+v_{i t} \text {, }
$$

\footnotetext{
${ }^{10}$ The inverse distance matrix is generated using the latitude and longitude information for countries: https:// developers.google.com/public-data/docs/canonical/countries_csv. Note that we also ran regressions with a contiguity matrix. Results are largely similar but inverse distance weighting allows more observations particularly from island nations, which would clearly be dropped from the regression analysis that uses contiguity weighting.
} 
where the error process can be written as a spatially autoregressive process. We will be showing results from both the SAR model and SEM, in addition to the ordinary least squares (OLS) regression that does not include any spatial correction in the next section. ${ }^{11}$

\section{EMPIRICAL RESULTS}

In the first set of regressions we are using panel data to examine the relationship between a government's policy on fertility and change in the total fertility rate. ${ }^{12}$ In table 1 we see a statistically significant negative association between change in the total fertility rate and government's anti-fertility policy. The results for antifertility policy show that an anti-fertility policy has both a negative direct and a negative indirect (or spatial spillover) association with the change in total fertility rate, which together lead to a strong negative total effect as indicated in column (3). The coefficient estimate for the SAR direct effect in column (1) shows that when there is an anti-fertility policy, change in total fertility rate is reduced by about 0.021 points. With an average total fertility growth rate of about -0.058 (or $-5.8 \%$ ) for the $1976-2013$ period, this translates into about $35 \%$ of the fertility growth rate on average. We see similar but smaller coefficient estimates in the SEM and OLS regressions in columns (4) and (5). While we get a consistently negative and significant coefficient for anti-fertility policy in all three regression specifications, it is important to note that the magnitude of the association with change in total fertility rate is substantially greater when direct and indirect (spillover) results are combined together in the SAR model results. We also see that both spatial parameters (rho and lambda) are positive and statistically significant.

In tables 2 and 3 , we do not see any significant relationship between the change in total fertility rate and pro-fertility policy or family planning policy. The latter result (in table 3) is consistent with the evidence from Pritchett (1994), in which evidence suggested the desired fertility of families mattered more than family planning policies.

\footnotetext{
${ }^{11}$ The OLS regression specification is very similar to the one shown in equation 2 , with the exception that the error term is not subject to the spatially autoregressive process. That specification can be written as Change in fertility rate it $=\alpha_{0}+\beta \mathrm{X}_{\mathrm{it}}+\gamma_{\mathrm{i}}+\tau_{\mathrm{t}}+\varepsilon_{\mathrm{it}}$.

${ }^{12}$ Please see the list of countries used in different regression specifications and the countries left out in tables A1-A3.
} 
TABLE 1

Change in total fertility rate and government's anti-fertility policy

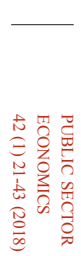

\begin{tabular}{|c|c|c|c|c|c|}
\hline $\begin{array}{l}\text { Dependent } \\
\text { variable }\end{array}$ & (1) & (2) & (3) & (4) & (5) \\
\hline $\begin{array}{l}\text { Change in } \\
\text { total fertility } \\
\text { rate }\end{array}$ & SAR & SAR & SAR & SEM & OLS \\
\hline Variables & Direct & Indirect & Total & & \\
\hline $\begin{array}{l}\text { Anti-fertility } \\
\text { policy }\end{array}$ & $\begin{array}{l}-0.0205^{* * *} \\
(0.0067)\end{array}$ & $\begin{array}{c}-0.116^{*} \\
(0.0670)\end{array}$ & $\begin{array}{c}-0.136^{*} \\
(0.0709)\end{array}$ & $\begin{array}{l}-0.0183^{* * *} \\
(0.0066)\end{array}$ & $\begin{array}{l}-0.0317 * * * \\
(0.0081)\end{array}$ \\
\hline $\begin{array}{l}\text { GDP per } \\
\text { capita } \\
\text { (\$ thousand) }\end{array}$ & $\begin{array}{l}0.00352 * * * \\
(0.001)\end{array}$ & $\begin{array}{l}0.0195^{* *} \\
(0.01)\end{array}$ & $\begin{array}{l}0.0230 * * \\
(0.01)\end{array}$ & $\begin{array}{c}0.00355^{* *} \\
(0.002)\end{array}$ & $\begin{array}{l}0.00803 * * * \\
(0.002)\end{array}$ \\
\hline $\begin{array}{l}\text { Health } \\
\text { spending } \\
\text { per capita } \\
\text { ( } \$ \text { thousand) }\end{array}$ & $\begin{array}{l}-0.0128^{* * *} \\
(0.004)\end{array}$ & $\begin{array}{c}-0.0733^{*} \\
(0.04)\end{array}$ & $\begin{array}{l}-0.0861 * * \\
(0.042)\end{array}$ & $\begin{array}{l}-0.0120 * * * \\
(0.004)\end{array}$ & $\begin{array}{c}-0.00817 * * \\
(0.004)\end{array}$ \\
\hline $\begin{array}{l}\text { Trade to } \\
\text { GDP }\end{array}$ & $\begin{array}{l}0.000259^{* *} \\
(0.0001)\end{array}$ & $\begin{array}{l}0.00146 \\
(0.0010) \\
\end{array}$ & $\begin{array}{l}0.00172 \\
(0.0011) \\
\end{array}$ & $\begin{array}{c}0.000265^{* *} \\
(0.0001) \\
\end{array}$ & $\begin{array}{c}0.000255^{* *} \\
(0.0001) \\
\end{array}$ \\
\hline $\begin{array}{l}\text { Share of } \\
\text { urban } \\
\text { population }\end{array}$ & $\begin{array}{l}0.00323 * * * \\
(0.0009)\end{array}$ & $\begin{array}{l}0.0176^{* *} \\
(0.0076)\end{array}$ & $\begin{array}{l}0.0209 * * * \\
(0.0080)\end{array}$ & $\begin{array}{l}0.00324 * * * \\
(0.0010)\end{array}$ & $\begin{array}{l}0.00725^{* * * *} \\
(0.0009)\end{array}$ \\
\hline $\begin{array}{l}\text { Spatial } \\
\text { parameter } \\
\text { (rho) }\end{array}$ & $\begin{array}{l}25.00 * * * \\
(1.1740)\end{array}$ & & & & \\
\hline $\begin{array}{l}\text { Spatial } \\
\text { parameter } \\
\text { (lambda) }\end{array}$ & & & & $25.78 * * *$ & \\
\hline Constant & & & & & $\begin{array}{l}-0.514 * * * \\
(0.0529)\end{array}$ \\
\hline Observations & 798 & 798 & 798 & 798 & 798 \\
\hline $\begin{array}{l}\text { Number of } \\
\text { countries }\end{array}$ & 133 & 133 & 133 & 133 & 133 \\
\hline $\begin{array}{l}\text { Econometric } \\
\text { model }\end{array}$ & SAR & SAR & SAR & SEM & $\mathrm{FE}$ \\
\hline $\begin{array}{l}\text { Country and } \\
\text { time fixed } \\
\text { effects }\end{array}$ & Yes & Yes & Yes & Yes & Yes \\
\hline
\end{tabular}

Standard errors in parentheses. $* * * p<0.01, * * p<0.05, * p<0.1$.

Results for the remaining control variables are quite consistent across all three regressions. While the coefficients for GDP per capita, trade-to-GDP ratio and share of urban population are positive and mostly statistically significant, the coefficient for health spending per capita is negative and statistically significant. While we find a negative and significant relationship between health spending per capita and the change in total fertility rate, it is hard to say whether this is driven by the decision of the couples to have fewer children due to better healthcare for their kids and themselves. It is also not possible to know with the data we have whether the quality of healthcare has improved over time in those countries that experienced lower fertility rates. There is also some evidence of a positive and significant relationship between urbanization and change in fertility. While we 
expect urbanization to have a negative association with change in fertility, it is possible that this happens after a certain threshold of urbanization is reached. Until that point we may still see an increase in fertility as less developed and less urbanized countries go through significant urbanization. Note that all regressions also control for time-invariant country fixed effects, which would include institutional differences between countries. It is also noteworthy that, in all three regressions, spatial dependence parameters (rho for the SAR and lambda for the SEM) are positive and significant. We have also examined spatial autocorrelation in total fertility rate and found a positive and significant Moran's I parameter, which we have already discussed in section 3. Hence, we indeed think spatial autocorrelation is a concern, which we control for in SAR and SEM regressions.

\section{TABLE 2}

Change in total fertility rate and government's pro-fertility policy

\begin{tabular}{|c|c|c|c|c|c|}
\hline $\begin{array}{l}\text { Dependent } \\
\text { variable }\end{array}$ & (1) & (2) & (3) & (4) & (5) \\
\hline $\begin{array}{l}\text { Change in } \\
\text { total fertility } \\
\text { rate }\end{array}$ & SAR & SAR & SAR & SEM & OLS \\
\hline Variables & Direct & Indirect & Total & & \\
\hline $\begin{array}{l}\text { Pro-fertility } \\
\text { policy }\end{array}$ & $\begin{array}{l}-0.00077 \\
(0.0060)\end{array}$ & $\begin{array}{r}-0.00598 \\
(0.0383)\end{array}$ & $\begin{array}{l}-0.00675 \\
(0.0438)\end{array}$ & $\begin{array}{l}-0.00384 \\
(0.0057)\end{array}$ & $\begin{array}{r}0.00917 \\
(0.0072)\end{array}$ \\
\hline $\begin{array}{l}\text { GDP per } \\
\text { capita } \\
\text { (\$ thousand) }\end{array}$ & $\begin{array}{l}0.00383^{* * *} \\
(0.001)\end{array}$ & $\begin{array}{l}0.0234^{* *} \\
(0.012)\end{array}$ & $\begin{array}{l}0.0272 * * \\
(0.013)\end{array}$ & $\begin{array}{l}0.00366^{* *} \\
(0.002)\end{array}$ & $\begin{array}{l}0.00825^{* * *} \\
(0.002)\end{array}$ \\
\hline $\begin{array}{l}\text { Health } \\
\text { spending } \\
\text { per capita } \\
\text { ( } \$ \text { thousand) }\end{array}$ & $\begin{array}{l}-0.0130^{* * *} \\
(0.004)\end{array}$ & $\begin{array}{c}-0.0825^{*} \\
(0.048)\end{array}$ & $\begin{array}{c}-0.0955^{*} \\
(0.05)\end{array}$ & $\begin{array}{l}-0.0119 * * * \\
(0.004)\end{array}$ & $\begin{array}{c}-0.00918^{* *} \\
(0.004)\end{array}$ \\
\hline $\begin{array}{l}\text { Trade to } \\
\text { GDP }\end{array}$ & $\begin{array}{c}0.000249 * * \\
(0.0001)\end{array}$ & $\begin{array}{l}0.00154 \\
(0.0011)\end{array}$ & $\begin{array}{l}0.00179 \\
(0.0012)\end{array}$ & $\begin{array}{l}0.000251^{* *} \\
(0.0001)\end{array}$ & $\begin{array}{c}0.000242^{*} \\
(0.0001)\end{array}$ \\
\hline $\begin{array}{l}\text { Share of } \\
\text { urban } \\
\text { population }\end{array}$ & $\begin{array}{l}0.00329 * * * \\
(0.0009)\end{array}$ & $\begin{array}{l}0.0199 * * \\
(0.0097)\end{array}$ & $\begin{array}{l}0.0231 * * \\
(0.0101)\end{array}$ & $\begin{array}{l}0.00329 * * * \\
(0.0010)\end{array}$ & $\begin{array}{l}0.00732^{* * *} \\
(0.0010)\end{array}$ \\
\hline $\begin{array}{l}\text { Spatial } \\
\text { parameter } \\
\text { (rho) }\end{array}$ & $\begin{array}{l}25.30^{* * * *} \\
(1.1290)\end{array}$ & & & & \\
\hline $\begin{array}{l}\text { Spatial } \\
\text { parameter } \\
\text { (lambda) }\end{array}$ & & & & $\begin{array}{l}25.92 * * * \\
(0.9920)\end{array}$ & \\
\hline Constant & & & & & $\begin{array}{l}-0.535^{* * *} \\
(0.0532)\end{array}$ \\
\hline Observations & 798 & 798 & 798 & 798 & 798 \\
\hline $\begin{array}{l}\text { Number of } \\
\text { countries }\end{array}$ & 133 & 133 & 133 & 133 & 133 \\
\hline $\begin{array}{l}\text { Econometric } \\
\text { model }\end{array}$ & SAR & SAR & SAR & SEM & $\mathrm{FE}$ \\
\hline $\begin{array}{l}\text { Country and } \\
\text { time fixed } \\
\text { effects }\end{array}$ & Yes & Yes & Yes & Yes & Yes \\
\hline
\end{tabular}

Clustered standard errors in parentheses. $* * * p<0.01, * * p<0.05, * p<0.1$. 
TABLE 3

Change in total fertility rate and government's family planning policy

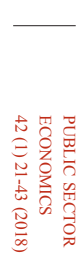

\begin{tabular}{|c|c|c|c|c|c|}
\hline $\begin{array}{l}\text { Dependent } \\
\text { variable }\end{array}$ & (1) & (2) & (3) & (4) & (5) \\
\hline $\begin{array}{l}\text { Change in } \\
\text { total fertility } \\
\text { rate }\end{array}$ & SAR & SAR & SAR & SEM & OLS \\
\hline Variables & Direct & Indirect & Total & & \\
\hline $\begin{array}{l}\text { Family } \\
\text { planning } \\
\text { policy }\end{array}$ & $\begin{array}{l}0.00583 \\
(0.0255)\end{array}$ & $\begin{array}{r}0.0437 \\
(0.1960)\end{array}$ & $\begin{array}{r}0.0496 \\
(0.2180)\end{array}$ & $\begin{array}{l}0.00523 \\
(0.0241)\end{array}$ & $\begin{array}{l}0.00903 \\
(0.0266)\end{array}$ \\
\hline $\begin{array}{l}\text { GDP per } \\
\text { capita } \\
\text { (\$ thousand) }\end{array}$ & $\begin{array}{c}0.00369^{*} \\
(0.002)\end{array}$ & $\begin{array}{l}0.0236 \\
(0.019)\end{array}$ & $\begin{array}{r}0.0273 \\
(0.021)\end{array}$ & $\begin{array}{r}0.00359 \\
(0.003)\end{array}$ & $\begin{array}{l}0.00849 * * * \\
(0.003)\end{array}$ \\
\hline $\begin{array}{l}\text { Health } \\
\text { spending } \\
\text { per capita } \\
\text { ( } \$ \text { thousand) }\end{array}$ & $\begin{array}{l}-0.0127 * * \\
(0.006)\end{array}$ & $\begin{array}{r}-0.0822 \\
(0.063)\end{array}$ & $\begin{array}{r}-0.0949 \\
(0.066)\end{array}$ & $\begin{array}{l}-0.0123^{* *} \\
(0.006)\end{array}$ & $\begin{array}{r}-0.00830 \\
(0.005)\end{array}$ \\
\hline $\begin{array}{l}\text { Trade to } \\
\text { GDP }\end{array}$ & $\begin{array}{c}0.000254 * \\
(0.0001) \\
\end{array}$ & $\begin{array}{c}0.00179 \\
(0.0021)\end{array}$ & $\begin{array}{l}0.00204 \\
(0.0022)\end{array}$ & $\begin{array}{l}0.000258^{* *} \\
(0.0001)\end{array}$ & $\begin{array}{c}0.000246^{*} \\
(0.0001)\end{array}$ \\
\hline $\begin{array}{l}\text { Share of } \\
\text { urban } \\
\text { population }\end{array}$ & $\begin{array}{l}0.00321 * * \\
(0.0015)\end{array}$ & $\begin{array}{r}0.0215 \\
(0.0237)\end{array}$ & $\begin{array}{r}0.0247 \\
(0.0245)\end{array}$ & $\begin{array}{l}0.00324 * \\
(0.0017)\end{array}$ & $\begin{array}{l}0.00735^{* * * *} \\
(0.0014)\end{array}$ \\
\hline $\begin{array}{l}\text { Spatial } \\
\text { parameter } \\
\text { (rho) }\end{array}$ & $\begin{array}{l}25.28^{* * * *} \\
(1.3270)\end{array}$ & & & & \\
\hline $\begin{array}{l}\text { Spatial } \\
\text { parameter } \\
\text { (lambda) }\end{array}$ & & & & $\begin{array}{l}25.88^{* * * *} \\
(1.2090)\end{array}$ & \\
\hline Constant & & & & & $\begin{array}{l}-0.546 * * * \\
(0.0808)\end{array}$ \\
\hline Observations & 798 & 798 & 798 & 798 & 798 \\
\hline $\begin{array}{l}\text { Number of } \\
\text { countries }\end{array}$ & 133 & 133 & 133 & 133 & 133 \\
\hline $\begin{array}{l}\text { Econometric } \\
\text { model }\end{array}$ & SAR & SAR & SAR & SEM & $\mathrm{FE}$ \\
\hline $\begin{array}{l}\text { Country and } \\
\text { time fixed } \\
\text { effects }\end{array}$ & Yes & Yes & Yes & Yes & Yes \\
\hline
\end{tabular}

Clustered standard errors in parentheses. $* * * p<0.01, * * p<0.05, * p<0.1$.

While the results in table 1 may make one think that anti-fertility policy has been effective in reducing total fertility rate, these results do not necessarily indicate causal links. It is possible that government policies are also driven by the total fertility rate. As another robustness check, in the next set of regressions, we are moving away from the panel data structure and regressing the change in the fertility rate between 1976 and 2013 on the 1976 value of the policy and other control variables. Results for the policy variables in tables 4-6 are quite similar to the ones in tables $1-3 .{ }^{13}$ We still see a negative and statistically significant association

\footnotetext{
${ }^{13}$ Note that we had to drop health spending per capita due to lack of data for that variable in 1976.
} 
between change in fertility rate and anti-fertility policy in all three regression specifications, and there is generally no significant association for other policy variables. ${ }^{14}$ Among the control variables, the only robust and significant relationship is for GDP per capita where the coefficient is positive. Also, the only robust and significant spatial parameter is for rho in the spatial lag (SAR) model, where the parameter is positive.

\section{Table 4}

Change in total fertility rate and government's anti-fertility policy

Variables

Anti-fertility policy

GDP per capita

(\$ thousand)

Trade to GDP

Share of urban

population

Constant

Spatial parameter
(lambda)

Spatial parameter

(rho)

Observations

Wald chi2(4)

Prob > chi2

Econometric model

Clustered standard errors in parentheses.
(1)
(2)

SAR
(3)

OLS

$-0.210 * * *$ $(0.0609)$

$0.0180^{* * *} \frac{(0.0149 * * *}{0.0179 * *}$

(0.00439)

$(0.00431)$

(0.00697)

0.0000679

$-0.00049$

0.0000846

(0.000661)

$(0.000612)$
-0.000645

(0.000536)

-0.00300 *

(0.0016)

$-0.00303^{*}$

$\frac{(0.00163)}{-0.406^{* * *}}$

$(0.146)$

$-0.0404$

(0.394)

$+$

$-0.625^{* *}$

(0.12)

(0.00181) $-0.394 * * *$ (0.0805) 
Variables

SEM

SAR

OLS

Spatial parameter

$-0.245$

(lambda)

$(0.4170)$

Spatial parameter

(rho)

Observations

Wald chi2(4)

102

Prob > chi2

27.6384

Econometric model

SEM

(0.1090)

Clustered standard errors in parentheses. ${ }^{* * *} p<0.01,{ }^{*} * p<0.05, * p<0.1$.

\section{TABle 6}

Change in total fertility rate and government's family planning policy

(1)

Variables

Family planning policy

GDP per capita

(\$ thousand)

Trade to GDP

Share of urban

population

Spatial parameter

(lambda)

Spatial parameter

(rho)

Observations

Wald chi2(4)

Prob > chi2

Econometric model
Constant

SEM

0.118

(0.0927)

$0.0207 * * *$

(0.005)

0.000247

(0.0007)

$-0.00136$

(0.0016)

$-0.754 * * *$

$(0.1610)$ $-0.277$

(0.4050)
(2)

SAR

$0.139 *$

(0.0798)

$0.0161 * * *$

(0.005)

$-0.0000804$

(0.0006)

0.000492

$(0.0016)$

$-0.696 * * *$

(0.1120)

$2.453 * * *$

$(0.3360)$

102

102

29.6418

19.8782

0.0005

Clustered standard errors in parentheses. ${ }^{* * *} p<0.01, * * p<0.05, * p<0.1$.

\section{SUMMARY AND CONCLUDING REMARKS}

In this paper, we find significant negative association between change in the total fertility rate and anti-fertility policy. On the other hand, there is no significant relationship for the pro-fertility policy or family planning policy, which makes it hard to conclude that government policy with respect to fertility works. It is possible that pro-fertility policy may not have been as strong (or long-lasting) as the anti-fertility policy. It is true that pro-fertility policies have become popular more recently. We may not be seeing the full impact of those policies on fertility rates empirically yet and can expect more countries to adopt such pro-fertility policies in the near future. We also need to consider the possibility of a change in culture towards a life with fewer children particularly in more developed coun- 
tries, which is hard to change with a pro-fertility policy. Additionally, as many scholars noted before, fertility behavior is quite complex which makes it hard to establish causal links between fertility and government policy. We also find evidence of spatial autocorrelation in the total fertility rate, and spatial spillovers from government's policy on fertility. It is noteworthy that there is significant spatial autocorrelation with fertility, which may explain the persistence of relatively high fertility in contiguous regions of Africa.

This study can be extended in a number of ways. Particularly, we find the data from the United Nations World Population Policies database to be quite rich. The dataset would allow one to examine government policies on other demographic variables such as population growth, population mobility and population aging, among others. At the same time, we should also caution that the database does not provide information specifically on the scope of government policies and data are not available annually. With this database, it is not possible to distinguish countries that pursue anti-fertility or pro-fertility policy more strongly than others. Having a policy may not be enough to impact fertility behavior, especially when the policy is seen as a relatively minor intervention by the government. One should also keep in mind that we had to drop a number of countries from our analysis due to lack of data in some regression specifications. We include a list of those countries in the appendix (see tables A1-A3 for a list of countries used in our regressions). This study can be followed by a micro study on a country or a group of countries, which may have more detailed information on individual or household characteristics.

\section{Disclosure statement}

No potential conflict of interest was reported by the authors. 


\section{Figure A1}

Moran Scatterplot

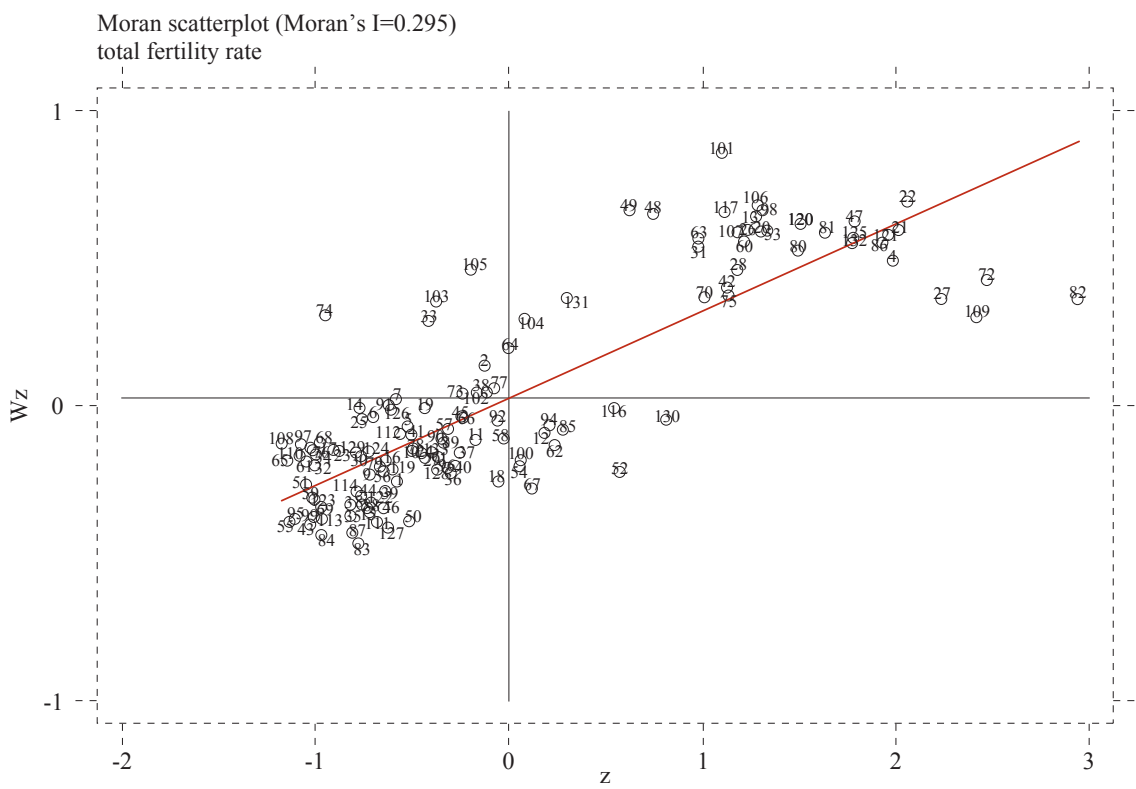

List of countries and codes in the Moran's I graph

\begin{tabular}{|c|c|c|c|c|c|c|c|}
\hline Africa & Code & Africa & Code & Oceania & Code & $\begin{array}{c}\text { Northern } \\
\text { America }\end{array}$ & Code \\
\hline Algeria & 2 & Mauritania & 75 & Australia & 6 & Canada & 17 \\
\hline Angola & 4 & Mauritius & 74 & Fiji & 45 & $\overline{\text { United States }}$ & 124 \\
\hline Benin & 13 & Morocco & 73 & Kiribati & 64 & & \\
\hline Botswana & 105 & $\overline{\text { Mozambique }}$ & 80 & New Zealand & 91 & & \\
\hline Burkina Faso & 125 & Niger & 82 & Samoa & 130 & & \\
\hline Burundi & 22 & Nigeria & 86 & Tonga & 116 & & \\
\hline Cabo Verde & 33 & Rwanda & 101 & Vanuatu & 85 & & \\
\hline Cameroon & 26 & Senegal & 106 & & & & \\
\hline $\begin{array}{l}\text { Central } \\
\text { African } \\
\text { Republic }\end{array}$ & 31 & Sierra Leone & 107 & & & & \\
\hline Chad & 27 & Somalia & 109 & & & & \\
\hline Comoros & 28 & South Africa & 103 & & & & \\
\hline $\begin{array}{l}\text { Congo, } \\
\text { Dem. Rep. }\end{array}$ & 21 & Swaziland & 131 & & & & \\
\hline Congo, Rep. & 20 & Tanzania & 120 & & & & \\
\hline Cote d'Ivoire & 60 & Togo & 117 & & & & \\
\hline $\begin{array}{l}\text { Egypt, } \\
\text { Arab Rep. }\end{array}$ & 38 & Tunisia & 118 & & & & \\
\hline $\begin{array}{l}\text { Equatorial } \\
\text { Guinea }\end{array}$ & 40 & Uganda & 121 & & & & \\
\hline
\end{tabular}


List of countries and codes in the Moran's I graph

\begin{tabular}{|c|c|c|c|c|c|c|c|}
\hline Africa & Code & Africa & Code & Oceania & Code & $\begin{array}{l}\text { Northern } \\
\text { America }\end{array}$ & Code \\
\hline Ethiopia & 42 & Zambia & 132 & & & & \\
\hline Gabon & 48 & & & & & & \\
\hline Gambia, The & 47 & & & & & & \\
\hline Ghana & 49 & & & & & & \\
\hline Guinea & 53 & & & & & & \\
\hline Guinea-Bissau & 98 & & & & & & \\
\hline Kenya & 63 & & & & & & \\
\hline Lesotho & 104 & & & & & & \\
\hline Madagascar & 70 & & & & & & \\
\hline Malawi & 81 & & & & & & \\
\hline Mali & 72 & & & & & & \\
\hline
\end{tabular}

List of countries and codes in the Moran's I graph (continued)

\begin{tabular}{|c|c|c|c|c|c|}
\hline Europe & Code & Asia & Code & Latin Amer. \& Caribbean & Code \\
\hline Albania & 3 & Bahrain & 7 & Antigua and Barbuda & 1 \\
\hline Austria & 43 & Bangladesh & 10 & Argentina & 5 \\
\hline Belarus & 69 & Bhutan & 24 & Bahamas, The & 9 \\
\hline Belgium & 83 & $\begin{array}{l}\text { Brunei } \\
\text { Darussalam }\end{array}$ & 16 & Barbados & 8 \\
\hline Bulgaria & 15 & Cambodia & 18 & Belize & 11 \\
\hline Denmark & 35 & China & 23 & Bolivia & 12 \\
\hline Finland & 44 & Cyprus & 34 & Brazil & 14 \\
\hline France & 46 & India & 57 & Chile & 25 \\
\hline Greece & 51 & Indonesia & 133 & Colombia & 29 \\
\hline Hungary & 55 & Israel & 58 & Costa Rica & 30 \\
\hline Iceland & 56 & Japan & 61 & Cuba & 32 \\
\hline Ireland & 39 & Jordan & 62 & Dominican Republic & 36 \\
\hline Italy & 59 & Korea, Rep. & 65 & Ecuador & 37 \\
\hline Luxembourg & 84 & Kuwait & 66 & El Salvador & 41 \\
\hline Malta & 76 & Lao PDR & 67 & Grenada & 50 \\
\hline Netherlands & 87 & Lebanon & 68 & Guatemala & 52 \\
\hline Norway & 88 & Malaysia & 79 & Honduras & 54 \\
\hline Poland & 95 & Mongolia & 71 & Mexico & 78 \\
\hline Portugal & 97 & Nepal & 89 & Nicaragua & 90 \\
\hline Romania & 99 & Oman & 77 & Panama & 96 \\
\hline Spain & 110 & Pakistan & 94 & Paraguay & 92 \\
\hline Sweden & 112 & Philippines & 100 & Peru & 93 \\
\hline Switzerland & 113 & Saudi Arabia & 102 & St. Lucia & 111 \\
\hline Ukraine & 123 & Singapore & 108 & St. Vincent and the Grenadines & 127 \\
\hline \multirow[t]{4}{*}{$\begin{array}{l}\text { United } \\
\text { Kingdom }\end{array}$} & 122 & Sri Lanka & 19 & Trinidad and Tobago & 114 \\
\hline & & Thailand & 115 & Uruguay & 126 \\
\hline & & Turkey & 119 & Venezuela, RB & 128 \\
\hline & & Vietnam & 129 & & \\
\hline
\end{tabular}


Table A1

Regions and names of countries included in table 1-3 regressions

\begin{tabular}{|c|c|c|c|c|c|}
\hline Africa1 & Africa2 & Europe & Asia & $\begin{array}{l}\text { Latin Amer. } \\
\text { \& Caribbean }\end{array}$ & Oceania \\
\hline Algeria & Mauritius & Albania & Bahrain & Argentina & Fiji \\
\hline Angola & Morocco & Austria & Bangladesh & Bahamas & Kiribati \\
\hline Benin & Mozambique & Belarus & Bhutan & Barbados & New Zealand \\
\hline Botswana & Niger & Belgium & $\begin{array}{l}\text { Brunei } \\
\text { Darussalam }\end{array}$ & Belize & Samoa \\
\hline Burkina Faso & Nigeria & Bulgaria & Cambodia & Bolivia & Tonga \\
\hline Burundi & Rwanda & Denmark & China & Brazil & Vanuatu \\
\hline Cameroon & Senegal & Finland & Cyprus & Chile & $\begin{array}{l}\text { Antigua and } \\
\text { Barbuda }\end{array}$ \\
\hline Cape Verde & Sierra Leone & France & India & Colombia & \\
\hline $\begin{array}{l}\text { Central } \\
\text { African } \\
\text { Republic }\end{array}$ & Somalia & Greece & Indonesia & Costa Rica & \\
\hline Chad & South Africa & Hungary & Israel & Cuba & \\
\hline Comoros & Swaziland & Iceland & Japan & $\begin{array}{l}\text { Dominican } \\
\text { Republic }\end{array}$ & \\
\hline Congo & Togo & Ireland & Jordan & Ecuador & \\
\hline Cote d'Ivoire & Tunisia & Italy & $\begin{array}{l}\text { Korea, } \\
\text { Republic of }\end{array}$ & El Salvador & \\
\hline $\begin{array}{l}\text { Congo, } \\
\text { Dem. Rep. }\end{array}$ & Uganda & Luxembourg & Kuwait & Grenada & \\
\hline Egypt & Tanzania & Malta & Lao & Guatemala & \\
\hline $\begin{array}{l}\text { Equatorial } \\
\text { Guinea }\end{array}$ & Zambia & Netherlands & Lebanon & Honduras & \\
\hline Ethiopia & & Norway & Malaysia & Mexico & \\
\hline Gabon & & Poland & Mongolia & Nicaragua & \\
\hline Gambia & & Portugal & Nepal & Panama & \\
\hline Ghana & & Romania & Oman & Paraguay & \\
\hline Guinea & & Spain & Pakistan & Peru & \\
\hline $\begin{array}{l}\text { Guinea- } \\
\text { Bissau }\end{array}$ & & Sweden & Philippines & Saint Lucia & \\
\hline Kenya & & Switzerland & Saudi Arabia & $\begin{array}{l}\text { Saint Vincent } \\
\text { and the } \\
\text { Grenadines }\end{array}$ & \\
\hline Lesotho & & Ukraine & Singapore & $\begin{array}{l}\text { Trinidad and } \\
\text { Tobago }\end{array}$ & \\
\hline Madagascar & & $\begin{array}{l}\text { United } \\
\text { Kingdom }\end{array}$ & Sri Lanka & Uruguay & \\
\hline Malawi & & & Thailand & Venezuela & \\
\hline Mali & & & Turkey & & \\
\hline Mauritania & & & Vietnam & & \\
\hline
\end{tabular}


Table A2

Regions and names of countries included in table 4-6 regressions

\begin{tabular}{|c|c|c|c|c|c|c|}
\hline Africa1 & Africa2 & Europe & Asia & $\begin{array}{c}\text { Latin } \\
\text { Amer. \& } \\
\text { Caribbean }\end{array}$ & Oceania & $\begin{array}{c}\text { Northern } \\
\text { America }\end{array}$ \\
\hline Algeria & Mali & Austria & Bangladesh & Argentina & Australia & Canada \\
\hline Benin & Mauritania & Belgium & $\begin{array}{l}\text { Brunei } \\
\text { Darussalam }\end{array}$ & Barbados & Fiji & $\begin{array}{l}\text { United } \\
\text { States }\end{array}$ \\
\hline Botswana & Mauritius & Denmark & China & Bolivia & Kiribati & \\
\hline $\begin{array}{l}\text { Burkina } \\
\text { Faso }\end{array}$ & Morocco & Finland & Cyprus & Brazil & $\begin{array}{l}\text { Papua } \\
\text { New } \\
\text { Guinea }\end{array}$ & \\
\hline Burundi & Niger & France & India & Chile & & \\
\hline Cameroon & Nigeria & Greece & Indonesia & Colombia & & \\
\hline $\begin{array}{l}\text { Central } \\
\text { African } \\
\text { Republic }\end{array}$ & Rwanda & Iceland & $\begin{array}{l}\text { Iran, } \\
\text { Islamic } \\
\text { Rep. }\end{array}$ & Costa Rica & & \\
\hline Chad & Seychelles & Ireland & Israel & Cuba & & \\
\hline Congo, Rep. & $\begin{array}{l}\text { Sierra } \\
\text { Leone }\end{array}$ & Italy & Japan & $\begin{array}{l}\text { Dominican } \\
\text { Republic }\end{array}$ & & \\
\hline $\begin{array}{l}\text { Cote } \\
\text { d'Ivoire }\end{array}$ & Somalia & Luxembourg & Jordan & Ecuador & & \\
\hline $\begin{array}{l}\text { Congo, } \\
\text { Dem. Rep. }\end{array}$ & $\begin{array}{l}\text { South } \\
\text { Africa }\end{array}$ & Malta & $\begin{array}{l}\text { Korea, } \\
\text { Rep. }\end{array}$ & El Salvador & & \\
\hline $\begin{array}{l}\text { Egypt, } \\
\text { Arab Rep. }\end{array}$ & Swaziland & Netherlands & Malaysia & Guatemala & & \\
\hline Gabon & Togo & Norway & Nepal & Guyana & & \\
\hline $\begin{array}{l}\text { Gambia, } \\
\text { The }\end{array}$ & Tunisia & Portugal & Oman & Honduras & & \\
\hline Ghana & Zambia & Spain & Pakistan & Mexico & & \\
\hline $\begin{array}{l}\text { Guinea- } \\
\text { Bissau }\end{array}$ & Zimbabwe & Sweden & Philippines & Nicaragua & & \\
\hline Kenya & & $\begin{array}{l}\text { United } \\
\text { Kingdom }\end{array}$ & $\begin{array}{l}\text { Saudi } \\
\text { Arabia }\end{array}$ & Peru & & \\
\hline Lesotho & & & Sri Lanka & Suriname & & \\
\hline Liberia & & & $\begin{array}{l}\text { Syrian } \\
\text { Arab } \\
\text { Republic }\end{array}$ & $\begin{array}{l}\text { Trinidad } \\
\text { and Tobago }\end{array}$ & & \\
\hline Madagascar & & & Thailand & Uruguay & & \\
\hline Malawi & & & Turkey & $\begin{array}{l}\text { Venezuela, } \\
\text { RB }\end{array}$ & & \\
\hline
\end{tabular}


TABLE A3

Missing countries from the table 4-6 regressions

$\begin{array}{llll}\text { Africa } & \text { Europe } & \text { Asia } & \text { Latin Amer. \& }\end{array}$ Caribbean

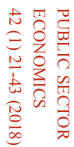

\begin{tabular}{|c|c|c|c|c|}
\hline & & & & \\
\hline Comoros & Belarus & Kuwait & Belize & Samoa \\
\hline Cabo Verde & Hungary & Singapore & $\begin{array}{l}\text { Antigua and } \\
\text { Barbuda }\end{array}$ & Vanuatu \\
\hline Senegal & Switzerland & Bahrain & St. Lucia & Tonga \\
\hline $\begin{array}{l}\text { Equatorial } \\
\text { Guinea }\end{array}$ & Ukraine & Lao PDR & Panama & New Zealand \\
\hline Uganda & Albania & Bhutan & Grenada & \\
\hline Ethiopia & Romania & Lebanon & $\begin{array}{l}\text { St. Vincent and } \\
\text { the Grenadines }\end{array}$ & \\
\hline Guinea & Poland & Mongolia & Bahamas, The & \\
\hline Angola & Bulgaria & Cambodia & Paraguay & \\
\hline Tanzania & & Vietnam & & \\
\hline Mozambique & & & & \\
\hline
\end{tabular}

Missing countries from the table 1-3 regressions

\begin{tabular}{|c|c|c|c|c|}
\hline Africa & Europe & Asia & $\begin{array}{c}\text { Latin Amer. \& } \\
\text { Caribbean }\end{array}$ & Oceania \\
\hline Seychelles & & $\begin{array}{l}\text { Iran, Islamic } \\
\text { Rep. }\end{array}$ & Guyana & $\begin{array}{l}\text { Papua New } \\
\text { Guinea }\end{array}$ \\
\hline Liberia & & $\begin{array}{l}\text { Syrian Arab } \\
\text { Republic }\end{array}$ & Suriname & \\
\hline Zimbabwe & & & & \\
\hline
\end{tabular}




\section{REFERENCES}

1. Anselin, L., 1988. Spatial Econometrics: Methods and Models. Dordrecht: Kluwer Academic. doi: 10.1007/978-94-015-7799-1

2. Becker, G. S., 1960. An Economic Analysis of Fertility in: R. Easterlin, ed. Demographic and Economic Change in Developing Countries. Princeton: Princeton University Press, pp. 209-240.

3. Bradshaw, J. and Attar-Schwartz, S., 2011. Fertility and Social Policy in: N. Takayama and M. Werding, eds. Fertility and Public Policy: How to Reverse the Trend of Declining Birth Rates. Cambridge, MA: The MIT Press, pp. 185-212.

4. Cliff, A. and Ord, J., 1981. Spatial Processes: Models and Applications. London: Taylor \& Francis.

5. Easterly, W. and Levine, R., 1998. Troubles with the Neighbours: Africa's Problem, Africa's Opportunity. Journal of African Economies, 7(1), pp. 120142. doi: 10.1093/oxfordjournals.jae.a020941

6. Feyrer, J., Sacerdote, B. and Stern, A. D., 2008. Will the stork return to Europe and Japan? Understanding fertility within developed nations. Journal of Economic Perspectives, 22(3), pp. 3-22. doi: 10.1257/jep.22.3.3

7. Haub, C., 2010. Did South Korea's Population Policy Work Too Well? Washington, D.C.: Population Reference Bureau.

8. Kim, J. and Prskawetz, A., 2006. External Shocks, Household Consumption and Fertility in Indonesia. Vienna Institute of Demography Working Papers, No. 4.

9. Parent, O. and Zouache, A., 2012. Geography versus Institutions: New Perspectives on the Growth of Africa and the Middle East. Journal of Institutional and TheoreticalEconomics, 168(3),pp.488-518. doi: 10.1628/093245612802921006

10. Pritchett, L. H., 1994. Desired Fertility and the Impact of Population Policies. Population and Development Review, 20(1), pp. 1-55. doi: 10.2307/2137629

11. Razin, A. and Sadka, S., 1995. Population Economics. Cambridge, MA: The MIT Press.

12. Takayama, N. and Werding, M., 2011. Fertility and Public Policy: How to Reverse the Trend of Declining Birth Rates. Cambridge, MA: The MIT Press.

13. United Nations, 2013. World Population Policies 2013. New York: United Nations, Department of Economic and Social Affairs, Population Division.

14. Yap, M. T., 2003. Fertility and Population Policy: the Singapore Experience. Journal of Population and Social Security (Population). Supplement to Volume 1, pp. 643-658. 